to involve himself with Marinov's theories. Unfortunately, Marinov construed this as consent to have his signature added to the preface. Although a number of people entreated Marinov to withdraw it, he refused, saying that as it had appeared in Pourquoi Pas? it was now too late to do so. Moreover, he needed Sakharov's name to sell the book; unless he could sell 5,000 copies at $\$ 20$ each he could not get the money he needed to carry out the experiments described in it. (One presumes he meant 'replicate'.) A long and hysterical telex was dis- patched to Sakharov c/o the Soviet Academy, and copies circulated among the Biennale journalists. Sakharov at that time was not even in Moscow; he and his wife were staging a sit-in in a Siberian labour camp where her nephew Edvard Kuznetsov, the dissident writer, had been refused his regular visit from the Sakharovs. At the time of writing, Marinov is still trying to get a message through to Sakharov.

Marinov's experiences in defence of his theories have undoubtedly made him only the more adamant in maintaining them. His poems imply that his incarceration in the mental hospital was on account of his theories (see sonnet opposite). Clearly he is willing to take any means to promulgate them, even resorting to 'short cuts' when no answer is forthcoming. This is almost certainly not the first such occurrence in the long history of East European censorship-a number of very curious documents have reached the West from time to time. The whole episode is yet another illustration of the curious situations which can arise when governments restrict the freedom of scientific contact and correspondence.

Vera Rich

\title{
Polishing a tarnished image
}

LAST Wednesday the centre of Washingtion was brought to a standstill by a demonstration of angry farmers demanding " $100 \%$ parity" — a price for their products that would give them the buying power of 65 years ago, when agricultural prices were at their peak. That same afternoon, a group of congressional employees was given a seminar on "government's role in scientific research" by a group of distinguished biomedical scientists, including three Nobel laureates-Anthur Kornberg, George Palade and James D. Watson-and the heads of some of America's leading biomedical research institutions and medical schools.

The style was different from that of the farmers, but the demand was very similar: a return to the levels of funding that basic research in the biological and medical sciences enjoyed in the relatively halcyon days of the late 1960s.

The case that the scientists presented during a well-organised two-day visit to Washington-which included private meetings with congressmen and members of the administration, as well as public hearings before the appropriations committees of both the Senate and the House-was straightforward. Basic research, they claimed, is grossly underfunded in comparison with applied resarch-it is in a chronic state of instability and lacks the means of training a new generation of scientists.

"We are here to draw to the attention of our legislators the importance of basic biological research in the solution of major elements of our nation's health cane problems," Dr Mahlon Hoagland, President of the Worcester Foundation for Experimental Biology, and a major organiser of the Washington visit, told Senator Thomas Eagleton's appropriations subcommittee on the budget of the Department of Health, Education and Welfare.

On the surface, the argument was about money; the report in the New York Times carried the not unfamiliar headline "Scientists plunge into lobbying for mone medical research aid". And the scientists presented a carefullyquantified list of grievances.

For an example they claimed that there has been an $18 \%$ drop in the total amount of federal funds spent on basic research since 1967, and a reduction of $17 \%$ in support for scientistinitiated grants awarded by the National Institutes of Health (NIH) between 1967 and 1975 .

Between 1967 and 1977 there was a decrease in the proportion of grants funded to grant applications submitted from $53 \%$ to $33 \%$, they told the subcommittee. And the scientists also pointed out that there has been a decrease in funds for training young scientists from $18 \%$ of the NIH's extra mural budget in 1967 to $6.8 \%$ in 1976 .

The demands, too, were specific. The group said that it wanted the NIH to be provided with an across-the-board increase in funding of $10 \%$ in the fiscal year 1979 to compensate for the effects of inflation, and a neturn to 1967 levels in both scientist-initiated grants for basic research (then $61 \%$ of the NIH external budget) and the biomedical research support grants system (then $7 \%$ ).

In addition, they requested an extra $\$ 100$ million a year for five years (an increase of almost $50 \%$ over the current budget) to be added to the budget of the National Institutes of General Medical Science, the NIH's basic research institute through which many biomedical research activities in universities and medical schools are funded.

Yet the visit to Washington was not only - or indeed primarily - about money. Indeed on purely statistical grounds, the case that the scientists presented lay open to criticism. It was pointed out, for example, that by taking the 1967 figure as a bench-mark, a year in which research funding is generally reckoned to have reached the peak of the 1960 s expansion, figures for subsequent years appear particularly-and perhaps artificially-bad. And figures presented purely as percentages obscure the almost 300\% increase in total funding for NIH.

Furthermore both NIH and President Carter's Office of Science and Technology Policy have shown themselves to be aware of the current problems facing the basic research community: After what everyone agrees was a bleak period between 1967 and 1972, funds for basic resarch have been picking up, and will continue to do so if Congress accepts the suggested increases in President Carter's budget proposals presented this week.

But behind the dispute over financial resources lies a deeper issue of concern to the scientific community, the public image of science, and in particular of basic science on which Congress's willingness to provide additional funds ultimately stands.

In recent years, just as the debate over the implications of the Rothschild Repont in Britain have reflected growing demands for the "relevance" of medical science, so similar tendencies in the US have given rise to what has been called the "disease of the month" menitality with a philosophy that medical science should be primarily directed towards curing, rather than understanding a disease.

In this climate, as funds have come pouring in for research into diseaserelated programmes such as cancer and heart disease, resulting in the total NIH budget increasing from about $\$ 1,000$ million to over $\$ 2,500$ million in seven years, so basic research has-in relative terms-lagged behind, and the process of scientific discovery has, it is claimed, been both distorted and delayed.

In the eyes of many basic scientists the villain of the piece is the so-called "war against cancer" launched in 1971 
with President Nixon's much-heralded National Cancer Act, and responsible for an increase in cancer research funding from $\$ 180$ million in 1970 to almost $\$ 900$ million in 1978.

No one is claiming that the money has been entirely wasted. Much good science has been carried out under the cancer programme, and despite occasional widely-publicised lapses, few are prepared publicly to identify specific projects which they feel should not have been funded.

But various factors have led to a cooling off in Congress' initial enthusiasm for a massively-financed cancer research programme, and to increasing demands for a visible pay-off from its investment. These factors include data showing that, in spite of all the research and clinical advances, deaths from cancer continue to increase, and the growing evidence that many cancers are due to environmental causes, accessible to preventitive rather than curative techniques.

Congress' frustration at the lack of tangible results reinforces the view of those scientists who criticised the whole "target-oriented approach", to biomedical research funding from the beginning. The fear, however, is that a failure of strategy could result in a general disillusionment with the whole research enterprise, affecting both its basic and applied aspects.

Dr Arthur Kornberg, for example, professor of biochemistry at Stanford University, claims that it is very rare for a crash programme of biomedical research to succeed in its objective, but warns that failure also carries its price. "Progress in medicine rests on fundamental advances. You harm people by trying to do things prematurely-you destroy your credibility, and the whole of science suffers. We have seen this happen in recent years, and people are discouraged from entering a field which has come to be regarded as bad science."

Dr Kornberg criticises the extent to which research workers are increasingly required to keep their eyes on a fixed target. "At present we have to boot-leg under various guises if we want to carry out fundamental research. This has both the spirit and the content of scientific investigation."

The task therefore facing the biomedical community, confronted by an apparent failure to come up with the goods that congress-many feel unjustly -has demanded, is how to make it respectable to be seen giving money to basic research in the biological and medical sciences. Criticism of the cancer programme, for example, will be to no purpose if the net result is an overall reduction in NIH research funds, rather than a redirection of

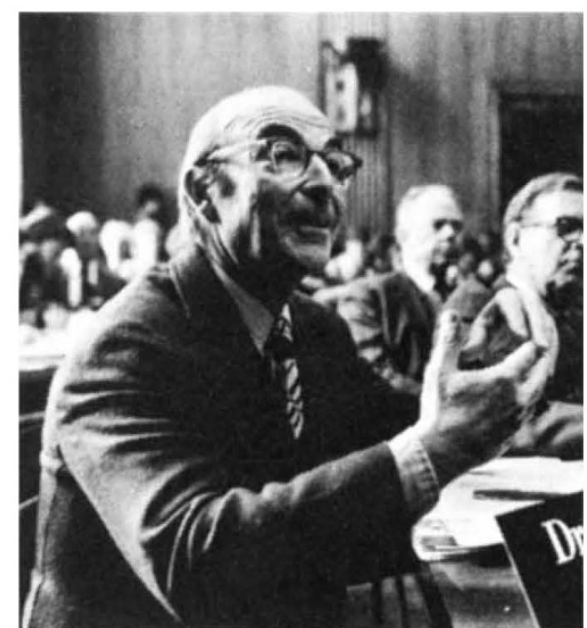

Dr Arthur Kornberg

funds towards basic research.

Furthermore Congress has no direct control over the way that the directors of the various NIH institutes distribute the funds allocated to them. A suggestion that each institute be required to spend at least $30 \%$ of its budget on basic research would be "a mistake" according to Dr Donald Frederickson, Director of NIH, who points out that most institutes do this already.

The best that scientists can hope for is some recommendation from Congress that it would like to see the various institutes upgrade basic research, a suggestion to be checked later against actual performance. "I feel that some of the institutes have tended to overemphasise target research at the expense of basic research because that was what Congress wanted. But Congress might now take the opportunity to communicate its belief in the importance of basic research," Dr Seymour Kety, Professor of Psychiatry at Harvard University and a past scientific director of the National Institute for Mental Health told the Senate Appropriations Subcommittee.

So far, the response of several key Congressmen has been relatively favourable. Sensing a growing disillusionment with the target-oriented approach to research funding, they are prepared to back the case that the long-term solutions lie in supporting basic research.

Mr Eagleton, for example, told the scientists that his subcommittee had "become aware of the pitfalls brought on by the proliferations of targeted research programmes." And Representative Paul D. Rogers, Chairman of the House Subcommittee on Health and the Environment, has promised to introduce a research training grants bill that would provide an extra $\$ 220$ million in 1979 .

But the case is far from conceded. Cancer research still has powerful supporters who, while accepting that it is the quality rather than the quantity of research that matters, claim that this means more rather than less money. And there remains the widespread feeling in many quarters-frequently voiced, for example, by Senator Edward Kennedy-that medical scientists should be required to produce results of visible social usefulness to justify the large investment of public funds that they receive.

Thus in spite of a significant increase in federal support for basic research in the proposed budget for 1979, basic biomedical science is unlikely to achieve its " $100 \%$ parity" with the boom years of the late $1960 \mathrm{~s}$. At least not in the near future. The most that scientists can hope for is that they can encourage the pendulum to swing a little faster in their direction.

David Dickson

\section{Lederberg named President of Rockefeller University}

Professor Joshua Lederberg, Chairman of the Department of Genetics at the Stanford University School of Medicine, and Nobel prize winner in 1958 for his work on the organisation of genetic material in bacteria, has been elected President of the Rockefeller University in New York. Professor Lederberg will take up his appointment from 1 July and succeed Dr Frederick Seitz.

\section{UK science budget announced for 1978/9}

Spending on science through the $U K$ research councils will be up by more than $2 \%$ in real terms in 1978/9, claim the Advisory Board for the Research Councils ( $A B R C$ ) following agreement between the Board and the Secretary of State for Education and Science on expenditure levels. The Science Budget, which funds the research councils, Natural History Museum and Royal Society, is 1256 million at 1977 prices; the Science Research Council get 1139 million of it. The figures include two increases recently authorised, one for a recurrent $£ 4$ million following a slight easing of the economic situation, the second for a once-off $£ 4.5$ million to stimulate the construction industry.

The distribution of the budget still reflects $A B R C$ 's intention gradually to redeploy resources away from big science but there is now sufficient leeway with the extra money for one person at SRC headquarters to describe the mood there as "reasonable satisfaction, even modified rapture". 